\title{
MANAGEMENT OF POWDERY MILDEW DISEASE OF RAMBUTAN (Nephelium lappaceum L.) IN SRI LANKA
}

\author{
R. G. A. S. Rajapakse ${ }^{1}$, E. R. S. P. Edirimanna ${ }^{1}$ and J. Kahawatta ${ }^{1}$
}

\section{ABSTRACT}

Powdery mildew disease is the most destructive disease of rambutan in Sri Lanka, which seriously threatens quality fruit production. Therefore, studies were conducted to identify the causal agent, cross infection potential of pathogen with other crops, resistant/tolerant germplasm and safer chemicals for management of powdery mildew of rambutan.

Pathogen of powdery mildew of rambutan was identified as Oidium nephelii. Pathogen did not show infection on leaves of rubber, mango, durian and orange which are potential hosts for Oidium species. All germplasm including recommended varieties were susceptible to the disease. Therefore, studies were directed to identify safer chemicals to control the disease. Spraying of wettable sulphur $(5 \mathrm{~g} / \mathrm{l}$.) at young foliage stage, at flowering, just after fruit setting and 3 weeks after fruit setting on to the plants completely controlled mildew disease of rambutan.

Key Word: Rambutan, Powdery Mildew, Oidium

\section{INTRODUCTION}

Rambutan production in Sri Lanka has suffered heavily in the recent past, due to the emergence of powdery mildew disease. A mild infection of this disease was noticed in year 2000 (Zoysa, 2000). However, it become a serious problem in 2001 causing economic losses to growers especially in Kandy, Kegalle, Gampaha and Colombo districts (Mithrasena, 2001; Anonymous, 2002). At present this disease has reached epidemic level in rambutan growing areas in the country. White powdery fungi appear first in patches on the young leaves, and then these enlarge to cover the entire surface of the leaves, flowers and immature fruits. Finally infected splinters of the fruits become discolored and dry off causing fruit quality deterioration and heavy fruit losses. Surface of the infected mature fruits become hard, turns black and may crack. Cultivars with sweet fruit reportedly are more susceptible than those with acidic fruit (Garcia, 1983). This disease is also prevalent in Thailand and Malayasia where the pathogen is identified as fungi Oidium nephelii. (Garcia, 1983; Coates et al., 2003). The fungi causing powdery mildew are obligatory parasites: they can not be cultured on artificial nutrient media. They produce mycelium that grows only on the surface of plant tissues, never invading the tissues themselves. They obtain nutrients from the plant by sending haustoria into the epidermal cells of the plant organs. Mycelium produces short conidiophores on the plant surface. Each conidiophore produces chains of egg-shaped conidia that are carried by air currents (Agrios, 1997). Powdery mildew on trees is effectively controlled with spraying of wettable sulfur or any of several sterolinhibiting systemic fungicides such as bitertanol, etaconazole and triforine.(Agrios, 1997; Tindall, 1994)). Powdery mildew of pea has also been controlled experimentally 
with spraying of azadirachtin EC, a natural product of neem (Azadirachta indica) (Singh and Prithiviraj, 1997).

Farmers did not pay much attention to this disease, as it was not a serious problem in year 2000. It can be assumed that the farmer's ignorance led to the severe outbreak of powdery mildew in year 2001. Climatic conditions i.e. intermittent showers with high temperature, very high humidity and less blowing experienced during March to July 2001 may positively contributed to the powdery mildew outbreak in rambutan. Some tentative recommendations have been given by Department of Agriculture to manage this disease. It includes removing of unwanted branches like water shoots, dead woods to open the canopy for sunlight and to improve ventilation within the canopy and inspection of trees closely for white mycelium on leaves and fruits and spraying of fungicides such as Chlorothalonil 500 SC, Thiophanate methyl 70 WP or Sulphur 80 WP immediately at $7-10$ days intervals when disease is observed (Anonymous, 2002). As a habit, fruit peel of rambutan removes with mouth and therefore, attention must be paid regarding the time of application and toxicity of the fungicides, which are used to control the disease. However, no detailed studies have been conducted in powdery mildew disease of rambutan in Sri Lanka. Therefore, studies were conducted to identify: causal agent, cross infection potential of pathogen with other crops, resistant/tolerant germplasm and safer chemicals for management of powdery mildew of rambutan.

\section{MATERIAL AND METHODS}

\section{Isolation and identification of pathogen}

Mildew affected leaves were collected from rambutan plants from different locations in Kandy, Gampaha and Kegalle districts. Powdery mildew affected leaf samples were microscopically observed for detection of morphological characters of mycelia and conidia of pathogen isolates and then these were compared with published data of Oidium nephelii. Conidia of pathogen were collected from powdery mildew affected leaves of rambutan plants and conidia suspensions of pathogen isolates $\left(10^{4}\right.$ conidia per $\mathrm{ml}$ of water) were prepared in distilled water. Then potted rambutan seedlings were artificially inoculated with these conidia suspensions by spraying conidia suspensions to study the development of symptoms on leaves. Conidia suspension of pathogen was cultured on potato dextrose agar and potato dextrose agar $+1 \%$ rambutan leaf extract media to detect the growing ability of pathogen on artificial media.

\section{Cross infection potential of mildew pathogen}

A suspension of conidia of mildew pathogen $\left(10^{4}\right.$ conidia per $\mathrm{ml}$. $)$ was prepared and drops of conidial suspension were placed on leaf surfaces of potted plants of rubber, mango, durian, orange and rambutan which are potential host for mildew pathogen. Then inoculated plants were incubated in humid chamber for 3 weeks to observe the disease development in different plants. 


\section{Pathogen differentiation on leaves of different rambutan varieties}

Conidia germination on surface of leaves of ten rambutan varieties was determined. Sets of leaves belonging to light green colour $\left(3^{\text {rd }}\right.$ leaf from top of the branch) was detached from five branches of each rambutan variety and washed with distilled water to clean the leaves. Suspension of conidia $\left(10^{4}\right.$ conidia per $\mathrm{ml}$.) of mildew pathogen was prepared and drops $(20 \mu \mathrm{l})$ of conidia suspension were placed at three places on each leaf surface. Then inoculated leaves were incubated in humid plastic boxes for $12 \mathrm{~h}$. Leaves were taken after incubation and used to determine the conidial germination on leaf surfaces by fixing inoculated leaves with lactophenol trypan blue. Treatments of this study (inoculated rambutan varieties + water control) were arranged as Completely Randomised Design with five replications. Leaf surfaces were observed by microscopically and germinated and ungerminated conidia were counted to calculate percentage germination of conidia on leaf surfaces of different varieties. Data were transformed to arc sign and analysed by MSTAT programme to identify variation of conidial differentiation on different rambutan varieties (Table 01).

\section{Identification of resistant/tolerant varieties to powdery mildew}

Study was conducted in rambutan orchard at Gannoruwa to identify resistant/tolerant varieties in the field under natural conditions of the infection. Disease severity index (DSI) of powdery mildew of ten rambutan varieties was measured using 0 - 5 rating scale. Five branches were randomly selected from each rambutan plant. Disease severity of mildew on leaves and fruits were measured using rating scale.

Rating scale for powdery mildew disease

On leaves -

0 - No disease symptoms on leaves

1 - Thin white colour mycelia were observed on less than $50 \%$ leaf area and leaves did

not become scorch

3 - Thin white colour mycelia were observed on leaves and leaves did not become scorch

5 - White colour mycelia were observed on leaves and leaves scorch

Disease severity index (DSI) of powdery mildew was calculated using the following formula.

DSI $(\%)=\underline{\text { Total sum of numerical ratings }}$

x 100

Maximum disease rating $\mathrm{x}$ no. of observations

On fruits

0 - No disease symptoms on fruits

1- Thin white colour mycelia were observed on less than $50 \%$ fruits and fruits did not

become shriveled or blackened (Mild disease severity)

3 - Thin white colour mycelia were observed on fruit surfaces but fruits did not become

shriveled and blackened

(Moderately high disease severity)
5 - White colour mycelia were observed on fruit surfaces and fruits become shriveled and blackened (High disease severity)

\section{Identification of effective and safe chemicals for management of powdery mildew}

Experiment in year 2003 - Effect of spraying of 3 botanicals and wettable sulphur on mildew disease were 
compared with untreated control (Table 2). Susceptible variety for mildew i.e. Malwana was used for the study. Experiment was arranged as Randomized Complete Block Design with 8 replicates. Chemicals were sprayed three times i.e. at fruit initiating stage, 10 days after fruit initiation and 20 days after fruit initiation by Knapsack sprayer. Disease severity (DS) of fruits was recorded using rating scale.

Experiment in year 2004 - Effect of spraying of 2 botanicals and sulphur on mildew disease were compared with untreated control (Table 3). Susceptible variety for mildew i.e. Malwana was used for the study. Experiment was arranged as Randomized Complete Block Design with 8 replicates. Chemicals were sprayed four times i.e. at young foliage stage, at flowering, 10 days after fruit setting and 20 days after fruit setting. Disease severity (DS) of fruits was recorded using rating scale.

Large scale field trials were conducted in rambutan orchard at Eramenigolla farm in year 2004 and 2005 to test the efficacy of sulphur treatment $(5 \mathrm{~g} / 1)$ in controlling powdery mildew disease of rambutan when sulphur spray into large trees by motor driven orchard sprayers. Twenty rambutan plants were selected (Variety - Malwana) and randomly selected fifteen plants were sprayed with wettable sulphur $(5 \mathrm{~g} / 1)$ at young foliage stage, at flowering, 10 days after fruit setting and 20 days after fruit setting. Five plants were kept as unsprayed control. Disease development on mature and ripen fruits of rambutan plants was observed.

\section{RESULTS AND DISCUSSION}

Symptoms developed on leaves which are artificially inoculated with Oidium isolates were similar to typical powdery mildew symptoms. Microscopic observations indicated that pathogen produced conidia openly at the end of hyphae and exposed to air. Conidia were unicellular, oval shape, $20-30 \mu$ diameters in size, arranged as long chains. Mycelia were septate and grown only on the surface of plants. These are the characteristics features of Oidium species (Anonymous, 1967). Pathogen did not culture on artificial media and disease symptoms developed only on leaves and fruits of rambutan plants. All isolates tested possessed common features which Garcia, (1983) described as typical for Oidium nephelii a causal agent of powdery mildew disease of rambutan in Phillippines. Therefore, causal agent of powdery mildew disease of rambutan in Sri Lanka can be recognized as Oidium nephelii, in agreement with reports from Philippine and Thailand (Garcia, 1983; Coates et al., 2003).

Cross infection studies indicated that conidia are germinated on leaves as well as in distilled water but failed to develop disease symptoms on leaves of rubber, mango, durian and citrus that are potential host for Oidium species. Therefore, powdery mildew pathogen of rambutan can be recognized as obligate parasites only on rambutan plants.

There was significant variation of conidia germination of Oidium on different rambutan varieties (Table 1). Higher conidia germination was occurred on leaf surfaces of variety Malwana, Labukabola, Simanjan, Sinjanjan as well as in distilled water. Higher DSI were also observed on leaves and fruits of these rambutan varieties. Therefore, percentage germination of conidia on leaves can be recognised as a indicator for 
susceptibility/resistance of rambutan varieties against powdery mildew pathogen. Among the available germplasm, var. Malwana,
Labukabola, No. 75, Simanjan and Sinjanjan were highly susceptible to powdery mildew pathogen under field conditions (Table 1).

Table 01: Conidia germination (\%) and disease severity index of mildew pathogen on leaf surfaces and disease severity index of mildew pathogen on fruits of different rambutan varieties.

\begin{tabular}{llll}
\hline Treatment (varieties) & $\begin{array}{l}\text { Mean conidia } \\
\text { germination (\%) }\end{array}$ & \multicolumn{2}{c}{$\begin{array}{l}\text { Disease severity index (\%) } \\
\text { on fruits }\end{array}$} \\
On leaves \\
\hline Malwana & $87(69.3)^{\mathrm{bc}}$ & $80(63.2)^{\mathrm{a}}$ & $46(42.6)^{\mathrm{a}}$ \\
Labukabola & $91(72.9)^{\mathrm{b}}$ & $72(58.1)^{\mathrm{ab}}$ & $36(36.9)^{\mathrm{b}}$ \\
Dadigama & $78(62.2)^{\mathrm{de}}$ & $44(41.6)^{\mathrm{b}}$ & $20(26.5)^{\mathrm{c}}$ \\
Malasiyan Red & $78(62.4)^{\mathrm{de}}$ & $58(49.2)^{\mathrm{c}}$ & $32(34.4)^{\mathrm{b}}$ \\
Java sp. & $77(61.6)^{\mathrm{de}}$ & $40(39.3)^{\mathrm{b}}$ & $26(30.6)^{\mathrm{b}}$ \\
No - 75 & $79(62.8)^{\mathrm{de}}$ & $82(64.9)^{\mathrm{a}}$ & $32(34.5)^{\mathrm{b}}$ \\
No - 169 & $73(59.5)^{\mathrm{e}}$ & $30(33.2)^{\mathrm{b}}$ & $26(30.7)^{\mathrm{b}}$ \\
Malasiyan yellow & $55(48.1)^{\mathrm{f}}$ & $40(39.1)^{\mathrm{b}}$ & $32(34.6)^{\mathrm{b}}$ \\
Simanjan & $83(65.9)^{\mathrm{cd}}$ & $86(68.0)^{\mathrm{a}}$ & $42(40.5)^{\mathrm{ab}}$ \\
Sinjanjan & $82(64.9)^{\mathrm{cde}}$ & $66(54.2)^{\mathrm{b}}$ & $50(45.1)^{\mathrm{a}}$ \\
Water control & $97(80.1)^{\mathrm{a}}$ & & \\
* Values followed by the same letters are not significantly different by DMRT at \\
p=0.05 \\
Values within brackets indicate arc sign transformed values
\end{tabular}

Table 02: Effect of spraying different chemicals on disease severity index of mildew of rambutan.

\begin{tabular}{lll}
\hline Chemicals & $\begin{array}{l}\text { Disease severity } \\
\text { on fruits (mean) }\end{array}$ & Disease severity level \\
\hline 1 Wettable sulphur, 5g/1. & $0.75(1.095)^{\mathrm{a}}$ & Mild \\
2 Neemarin $15 \%, 3 \mathrm{ml} / 1$. & $2.50(1.709)^{\mathrm{b}}$ & Moderately high \\
3 Neem seed extract, $5 \mathrm{~g} / 1$ & $2.25(1.628)^{\mathrm{g}}$ & Moderately high \\
4 Caster seed extract, $5 \mathrm{~g} / 1$ & $4.50(2.226)^{\mathrm{c}}$ & High \\
5 Unsprayed control & $5.00(2.345)^{\mathrm{c}}$ & High \\
\hline
\end{tabular}

* Values followed by the same letters are not significantly different by DMRT at $\mathrm{p}=0.05$

Values within brackets indicate square root values

Table 03: Effect of spraying different chemicals on disease severity index of mildew of rambutan.

\begin{tabular}{lll}
\hline Chemicals & $\begin{array}{l}\text { Disease severity } \\
\text { On fruits (mean) }\end{array}$ & Disease severity level \\
\hline 1 Wettable sulphur, $5 \mathrm{~g} / \mathrm{l}$. & $0.0(0.707)^{\mathrm{a}}$ & Mild \\
2 Neemarin $15 \%, 3 \mathrm{ml} / 1$. & $2.50(1.709)^{\mathrm{b}}$ & Moderately high \\
3 Neem seed extract, $5 \mathrm{~g} / 1$ & $2.25(1.628)^{\mathrm{b}}$ & Moderately high \\
4 Unsprayed control & $5.00(2.345)^{\mathrm{c}}$ & High \\
\hline
\end{tabular}


Results in year 2003 indicated that DS is high in fruits treated with castor seed extract and control treatment (Table 2). All fruits were shriveled and blackened in these treatments. Chemicals were sprayed three times i.e. at flowering stage, 10 days after fruit setting and 20 days after fruit setting. Application of Neemarin 15\% (azadirachtin 15\% EC, a commercial neem formulation) and neem seed extracts showed moderately high disease severity on fruits. In these treatments, thin white colour mycelia were observed on fruit surfaces but fruits did not become shriveled and blackened. Singh and Prithiviraj (1997) have reported that a product of neem significantly retarded conidia differentiation and symptom development of powdery mildew caused by Erysiphe on pea plants. However, these results indicated that neem extract or neem product do not effective much in controlling powdery mildew caused by Oidium nephelii on rambutan. Application of sulphur at flowering, 10 days after fruit setting and 20 days after fruit setting showed mild disease severity on mature fruits. Thin white colour mycelia were observed on less than $50 \%$ fruits and fruits did not become shriveled or blackened of sulphur applied treatment (Table 2).

Singh and Prithiviraj (1997) also revealed that application of neem formulation was more effective in controlling mildew disease when applied before symptom development on the plant probably due to development of immunity in the plants for diseases. Therefore, further testing was conducted to identify efficacy of neem products and wetteble sulphur treatments as less toxic chemicals for management of mildew of rambutan when spraying start at young foliage stage of trees.
Results in year 2004 indicated that DS is high in control treatment. All fruits were shriveled and blackened in this treatment. Although, chemicals were sprayed four times i.e. at young foliage stage, at flowering, 10 days after fruit setting and 20 days after fruit setting application of Neemarin 15\% (a commercial neem formulation) and neem seed extracts showed moderately high disease severity on fruits as in year 2003. In these treatments, thin white colour mycelia were observed on fruit surfaces but fruits did not become shriveled and blackened. However, these formulations were not effective on controlling powdery mildew of rambutan. Spraying of sulphur at four times i.e. at young foliage stage, at flowering, 10 days after fruit setting and 20 days after fruit setting did not show mildew symptom on leaves and mature fruits of rambutan (Table 3). Effectiveness of sulphur in controlling powdery mildew of rambutan were further concluded in trials conducted in rambutan orchard at Eraminigolla farm. Wettable sulphur (5g/ 1) was sprayed by motor driven orchard sprayer at four times i.e. at young foliage stage, at flowering, 10 days after fruit setting and 20 days after fruit setting and no disease symptoms were observed on immature or ripen fruits of rambutan.

\section{CONCLUSION}

Pathogen of powdery mildew of rambutan was identified as Oidium nephelii. Local germplasm including recommended varieties were susceptible to the disease. Pathogen did not show infection on leaves of rubber, mango, durian and orange which are potential hosts for Oidium species. Spraying of wettable sulphur $(5 \mathrm{~g} / \mathrm{l})$ at young foliage stage, at flowering, 10 days after fruit setting and 20 days after fruit setting completely controlled powdery mildew of rambutan. 


\section{References}

Agrios, G. N. (1997). Plant pathology. Academic Press, 295-298

Anonymous, (1967). C.M.I. description of pathogenic fungi and bacteria, Set 16, Kew,Surrey, England.

Anonymous, (2002). Powdery mildew of rambutan cultivation. Technology development, Leaflet No. 15. Horticultural Crop Research and Development Institute, Gannoruwa, Peradeniya, Sri Lanka.

Coates, L. M., S. Sangchote, D. I. Jononson and C. Sittigul (2003). Diseases of Longan, Lychee and Rambutan. Diseases of tropical fruit crops Edited by R. C. Ploetz. CABI Publishing, 307-325.

Garcia, A. S. (1983). The powdery mildew disease of rambutan. Philippine PhytoPathology, Vol. 19, Pp15-16

Mithrasena, Y. J. P. K. (2001). New threat to rambutan plantations. Annals of the Sri Lanka Department of Agriculture:2001, 3:395.

Singh, U. P. and B. Prithiviraj (1997). Neemazal, a product of neem (Azadirachta indica) induces resistance in pea (Pisum sativum) against Erysiphe pisi. Physiological andMolicular Plant Pathology. 51, 181-194.

Tindall, H. D. (1994). Rambutan cultivation. In: FAO plant production and protection paper No. 121, pp 135-141.

Zoysa, I. J. de. (2000). Powdery mildew of rambutan. AGTEC in brief, Technical news letter, Department of Agriculture, Sri Lanka, Nov. - Dec. 2000, Vol. 5, No.3:1. 